\title{
Metabolism of 3,5,3' -Triiodothyronine Sulfate by Tissues of the Fetal Rat: A Consideration of the Role of Desulfation of 3,5,3'-Triiodothyronine Sulfate as a Source of $\mathbf{T}_{3}$
}

\author{
FERRUCCIO SANTINI, INDER J. CHOPRA, SING-YUNG WU, DAVID H. SOLOMON, AND \\ GUADALUPE N. CHUA TECO \\ Department of Medicine, University of California School of Medicine, Los Angeles, California 90024
}

\begin{abstract}
We have recently demonstrated that serum concentration of $3,5,3^{\prime}$-triiodothyronine sulfate $\left(T_{3} S\right)$ is markedly elevated in the human newborn at a time when serum 3,5,3'-triiodothyronine $\left(T_{3}\right)$ is very low. The present study explores the ability of maternal (19-21 d pregnant) and near-term fetal Sprague-Dawley rat tissues to 1) monodeiodinate $T_{3} S$ and $T_{3}$ in both the outer and the inner ring and 2) desulfate $T_{3} S$ to $T_{3}$. Maternal liver microsomes metabolized $\mathrm{T}_{3} \mathrm{~S}$ exceedingly efficiently (compare fetus $p$ $<0.05$ ). Eighty percent or more of $\mathrm{T}_{3} \mathrm{~S}$ was consumed during its incubation with $360 \mu \mathrm{g} / \mathrm{mL}$ microsomes for $2 \mathrm{~h}$. The majority of the consumption of $T_{3} S$ by adult liver microsomes occurred by its $5^{\prime}$-monodeiodination to $\mathrm{I}^{-}$; little inner-ring monodeiodination to $3,3^{\prime}$-diiodothyronine was demonstrable. In fetal liver microsomes, however, over $75 \%$ of the substrate $T_{3} S$ remained unchanged after a $2-h$ incubation. $T_{3}$ was metabolized similarly moderately by fetal and maternal liver microsomes. Brain microsomes metabolized $\mathrm{T}_{3} \mathrm{~S}$ poorly in both the mother and the fetus. Over $90 \%$ of substrate $T_{3} S$ remained unchanged after a 2 $h$ incubation in each case. Interestingly, brain microsomes metabolized $T_{3}$ more rapidly than $T_{3} S(p<0.05)$. In the fetus, desulfation of $T_{3} S$ to $T_{3}$ was clearly evident only in microsomes from the liver and the brain; in the adult, it was plentiful in many tissues. Fetal liver and brain tissues metabolize $T_{3} S$ poorly, and both actively desulfate $T_{3} S$ to $T_{3}$. These data and those indicating high serum $T_{3} S$ in the fetus suggest that $T_{3} S$ is a local source of $T_{3}$ in critical tissues in the fetus and possibly in adults with the low $T_{3}$ syndrome. (Pediatr Res 31: 541-544, 1992)
\end{abstract}

Abbreviations

$T_{4}$, thyroxine

$\mathrm{rT}_{3}, 3,3^{\prime} 5^{\prime}$-triiodothyronine

$T_{3}, 3,5,3^{\prime}$-triiodothyronine

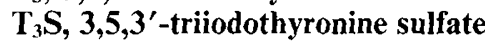

3,3'-T $\mathbf{T}_{2}, 3,3^{\prime}$-diiodothyronine

$3,3^{\prime}-T_{2} S, 3,3^{\prime}$-diiodothyronine sulfate

$\mathrm{T}_{4}$ is the predominant secretory product of the thyroid gland in man and experimental animals. The majority of $T_{4}$ produced

Received October 31, 1991; accepted February 4, 1992.

Reprint requests: Inder J. Chopra, M.D., Department of Medicine, UCLA Center for the Health Sciences, Los Angeles, CA 90024.

Supported by USPHS Grant DK-16155 (to I.J.C.) and Biomedical Research Support Grant No. H552-507-RR05354 (to UCLA) from the National Institutes of Heaith, Bethesda, MD. daily is metabolized in extrathyroidal tissues either by $5^{\prime}$-monodeiodination in the outer (phenolic) ring to a much $(\sim 3-5 \times)$ more active iodothyronine, $\mathrm{T}_{3}$, or by 5 -monodeiodination in the inner (tyrosyl) ring to a calorigenically inactive iodothyronine, $\mathrm{rT}_{3}$ (reverse $\mathrm{T}_{3}$ ). Over $75 \%$ of $\mathrm{T}_{3}$ and $95 \%$ of $\mathrm{rT}_{3}$ produced daily in man derive from extrathyroidal metabolism of $T_{4}$, and the rest is secreted by the thyroid. Several recent studies have examined the enzymic processes that activate (or inactivate) $T_{4}$ to $\mathrm{T}_{3}$ (or $\mathrm{rT}_{3}$ ). It is clear that these processes are carefully regulated by the activity of several monodeiodinase enzymes serving to generate an optimal supply of thyroid hormone for the tissues (1-3). $\mathrm{T}_{3}$ and $\mathrm{rT}_{3}$, like $\mathrm{T}_{4}$, are mainly metabolized by sequential monodeiodination in the outer and inner ring of the molecules until a completely deiodinated molecule, thyronine, is produced and excreted $(4,5)$.

Besides monodeiodination, thyroid hormones are also metabolized by conjugation of phenolic hydroxyl with either glucuronic acid or sulfate (3, Fig. 1). Such conjugation of compounds has generally been considered a means to inactivate and facilitate biliary and urinary excretion of hydrophobic aglycons (6). Sulfate conjugation of iodothyronines has evoked much interest recently (7-12). Thus, studies have shown a close interaction between sulfation and deiodination in a manner that may modulate the availability of the active thyroid hormone, $\mathrm{T}_{3}$, in the tissues. Thus, sulfation of the phenolic hydroxyl of the iodothyronines (Fig. 1) is associated with a marked enhancement of both their outer and inner ring monodeiodination by the type I monodeiodinase in the liver (7-11). Additionally, sulfate conjugates of $\mathrm{T}_{3}\left(\mathrm{~T}_{3} \mathrm{~S}\right)$ have now been measured in serum of man and experimental animals, and substantial increases have been observed in the fetus and newborn, in adults with hyperthyroidism and systemic illness, and in adults after administration of drugs that inhibit $5^{\prime}$-monodeiodination of iodothyronines $(9,10,13)$. Increased serum $\mathrm{T}_{3} \mathrm{~S}$ concentration in fetal sheep and human newborn cord blood has been especially intriguing. A recent study has demonstrated desulfation of $\mathrm{T}_{3} \mathrm{~S}$ to $\mathrm{T}_{3}$ by microsomes from some tissues and isolated hepatocytes of the adult rat (14). The present study was undertaken to gather insight into the metabolism of $T_{3} S$ and $T_{3}$ in the fetus and the influence of changes in this system on thyroid hormone economy in fetal life.

\section{MATERIALS AND METHODS}

Reagents. Chlorosulfonic acid, N,N dimethylformamide, and LH-20 Sephadex were purchased from Sigma Chemical Company, St. Louis, MO. Radioactive $\left({ }^{125} \mathrm{I}\right.$-labeled) $\mathrm{T}_{3}$ was purchased from New England Nuclear, Boston, MA; its sp act was approximately $1200 \mathrm{mCi} / \mathrm{mg}$. Radioactive $\mathrm{T}_{3} \mathrm{~S}$ was prepared by reacting ${ }^{125} \mathrm{I}_{-} \mathrm{T}_{3}$ overnight with a mixture of chlorosulfonic acid and $\mathrm{N}, \mathrm{N}$ dimethylformamide $(1 / 4, \mathrm{vol} / \mathrm{vol})$ at $0^{\circ} \mathrm{C}$ using the method of 


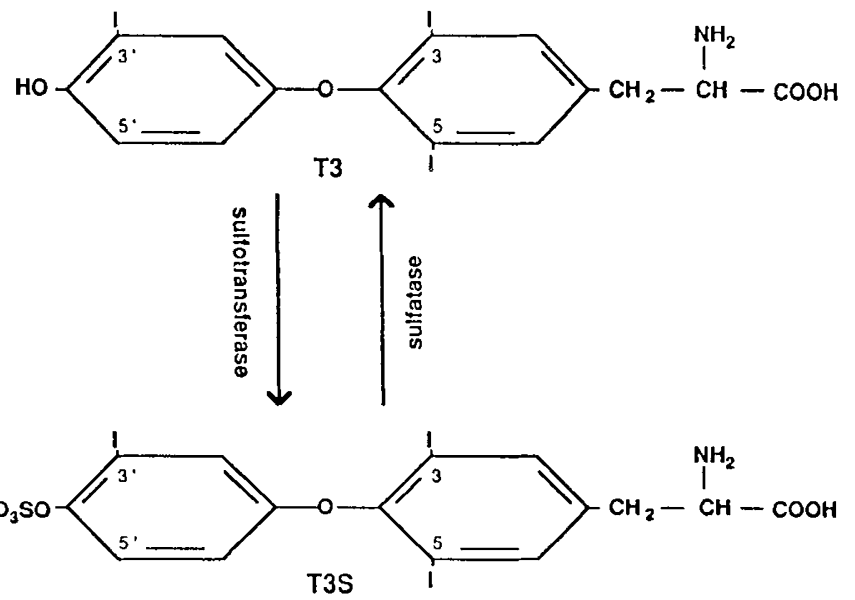

Fig. 1. The conversion of $T_{3}$ to $T_{3} S$ by sulfotransferase in the tissues and the conversion of $\Upsilon_{3} S$ back to the parent hormone $\Upsilon_{3}$ by sulfatases in the tissues is shown.

Mol and Visser (15). The reaction mixture was diluted with four volumes of cold $\left(0^{\circ} \mathrm{C}\right)$ water and applied to a small $(\sim 1-\mathrm{mL})$ column of LH-20 Sephadex. The column was washed sequentially with $4 \times 2 \mathrm{~mL}$ fractions of $0.1 \mathrm{~N}$ hydrochloric acid, $7 \times 2$ $\mathrm{mL}$ fractions of water, and $4 \times 2 \mathrm{~mL}$ fractions of $1 \mathrm{~N}$ ammonia in ethanol. $\mathrm{T}_{3} \mathrm{~S}$ was eluted with water.

Tissues. Fetal and maternal tissues were obtained from 19- to 21 -d pregnant Sprague-Dawley rats weighing about $320 \mathrm{~g}$. Tissues were homogenized in $50 \mathrm{mM}$ phosphate buffer ( $\mathrm{pH}$ 7.4) containing $1 \mathrm{mM}$ EDTA and $0.4 \mathrm{mM}$ phenylmethyl-sulfonylfluoride (Sigma Chemical Co.); microsomes were prepared as previously described (16) and suspended by sonication (Branson Sonic Power, Danbury, CT).

Study of $T_{3}$ and $T_{3} S$ metabolism. Deiodination. Microsomes from liver, cerebral cortex, and placenta $(0.25-1000 \mu \mathrm{g}$ protein/ $\mathrm{mL}$, final volume $0.5 \mathrm{~mL}$ ) were incubated in $0.1 \mathrm{M}$ Tris buffer with ${ }^{125} \mathrm{I}_{-} \mathrm{T}_{3}$ (or ${ }^{125} \mathrm{I}-\mathrm{T}_{3} \mathrm{~S}$, sp act $1200 \mathrm{mCi} / \mathrm{mg}, \sim 0.6 \mathrm{nM}$ ) as substrate and DTT $(10 \mathrm{mM})$ as a sulfhydryl donor-cofactor for $5 \mathrm{~min}$ to $4 \mathrm{~h}$ at $37^{\circ} \mathrm{C}$.

Outer ring $\left(5^{\prime}-\right)$ monodeiodination of the outer ring $\left(3^{\prime}\right.$ or $\left.5^{\prime}\right)$ labeled ${ }^{125} \mathrm{I}-\mathrm{T}_{3}$ (or ${ }^{125} 1-\mathrm{T}_{3} \mathrm{~S}$ ) to ${ }^{125} \mathrm{I}^{-}$by microsomes was studied at both pH 7.4 and 8.0 ; the data were essentially similar. After an incubation for $15 \mathrm{~min}$ to $4 \mathrm{~h}$, the reaction was stopped by addition of $100 \mu \mathrm{L}$ of $5 \%$ BSA to $200 \mu \mathrm{L}$ of sample followed by $200 \mu \mathrm{L}$ of $10 \%$ trichloroacetic acid. The mixture was centrifuged, and ${ }^{125} \mathrm{I}^{-}$in the supernatant was quantified as described previously (17)

The inner ring (5-) monodeiodination of ${ }^{125} \mathrm{I}^{-\mathrm{T}_{3}}\left(\right.$ or ${ }^{125} \mathrm{I}-\mathrm{T}_{3} \mathrm{~S}$ ) to $3,3^{\prime}-\mathrm{T}_{2}$ (or ${ }^{125} \mathrm{I}-3,3^{\prime}-\mathrm{T}_{2} \mathrm{~S}$ ) by microsomes was studied both at pH 7.4 and 8.0 ; the data were essentially similar. After incubation, two volumes of ethanol were added to an aliquot of the reaction mixture and the mixture was centrifuged. ${ }^{125} I-3,3^{\prime}-T_{2}$ was quantified in $75 \mu \mathrm{L}$ of the supernatant by incubation with a highly specific rabbit anti-3,3'- $\mathrm{T}_{2}$ antibody for $16 \mathrm{~h}$ at $4^{\circ} \mathrm{C}$ in a total volume of $1.0 \mathrm{~mL}$; the antibody-bound ${ }^{125} \mathrm{I}-3,3^{\prime}-\mathrm{T}_{2}$ was precipitated with a goat anti-rabbit gamma globulin (18). When ${ }^{125} \mathrm{I}-\mathrm{T}_{3} \mathrm{~S}$ was the substrate, ${ }^{125} \mathrm{I}-3,3^{\prime}-\mathrm{T}_{2} \mathrm{~S}$ produced during incubation was hydrolyzed to $3,3^{\prime}-\mathrm{T}_{2}$ by addition of $600 \mu \mathrm{L}$ of 1.0 $\mathrm{M} \mathrm{HCl}$ to $150 \mu \mathrm{L}$ of sample, followed by heating at $80^{\circ} \mathrm{C}$ for $1 \mathrm{~h}$ (15). Subsequently, the $\mathrm{pH}$ of the mixture was adjusted to 7.4 and ${ }^{125} \mathrm{I}-3,3^{\prime}-\mathrm{T}_{2}$ was quantified by binding to anti-3, $3^{\prime}-\mathrm{T}_{2}$ antibody (see above).

Radioactive $T_{3}$ remaining after incubation was quantified by incubating overnight at $4^{\circ} \mathrm{C} 75 \mu \mathrm{L}$ of an ethanol extract (see above) of the reaction mixture with a rabbit anti- $\mathrm{T}_{3}$ antibody. This was followed by addition of goat anti-rabbit gamma globulin to precipitate antibody bound ${ }^{125} \mathrm{I}_{-} \mathrm{T}_{3}$ (19). The results were expressed as the percentage of ${ }^{125} \mathrm{I}_{-} \mathrm{T}_{3}$ added to the reaction mixture in the beginning of the experiment. When ${ }^{125} \mathrm{I}-\mathrm{T}_{3} \mathrm{~S}$ was the substrate, its amount remaining after incubation was determined similarly except a highly specific rabbit anti- $\mathrm{T}_{3} \mathrm{~S}$ antibody was used in place of anti- $\mathrm{T}_{3}$ antibody. The anti- $\mathrm{T}_{3} \mathrm{~S}$ antibody cross-reacted less than $0.01 \%$ with $\mathrm{T}_{4}, \mathrm{~T}_{3}, \mathrm{rT}_{3}$, or $3,3^{\prime}-\mathrm{T}_{2}$ (13).

Desulfation. Desulfation of $\mathrm{T}_{3} \mathrm{~S}$ to $\mathrm{T}_{3}$ by various tissues was studied by incubating microsomes ( $200 \mu$ g protein) with nonradioactive $\mathrm{T}_{3} \mathrm{~S}(0.1-2.0 \mathrm{nmol})$ in $0.1 \mathrm{M}$ sodium phosphate buffer, $\mathrm{pH} 8.0$, for $2 \mathrm{~h}$ at $37^{\circ} \mathrm{C}$ (final incubation volume, $200 \mu \mathrm{L}$ ). The reaction was stopped by adding $100 \mu \mathrm{L}$ of $2.5 \%$ BSA followed by two volumes $(600 \mu \mathrm{L})$ of ethanol. The mixture was centrifuged and $\mathrm{T}_{3}$ was measured by RIA of $100 \mu \mathrm{L}$ of the supernatant as described previously (19). Each assay included two tubes (zero incubation tubes), which were handled as described above except that microsomes were added at the end of incubation immediately before extraction with ethanol. $\mathrm{T}_{3}$ measured in these tubes was considered present in $\mathrm{T}_{3} \mathrm{~S}$ or that apparent from crossreaction of $T_{3} S$ in $T_{3}$ RIA. This amount of apparent $T_{3}$ was subtracted from $\mathrm{T}_{3}$ measured in test specimens to determine the amount of $\mathrm{T}_{3}$ produced as a result of incubation of microsomes with $\mathrm{T}_{3} \mathrm{~S}$. Pilot studies using liver microsomes had demonstrated that the desulfation is linear 1 ) with $25-400 \mu \mathrm{g}$ of microsomal protein, 2) between $15 \mathrm{~min}$ and $4 \mathrm{~h}$ of incubation period, and 3) with $100-1500 \mathrm{pmol}$ of substrate. Additionally, the hepatic microsomal desulfation activity was greater at $37^{\circ} \mathrm{C}$ than at 25 or $4^{\circ} \mathrm{C}$, and it was inhibited by $0.15 \mathrm{mM}$ or more of DTT. Similar data were obtained using maternal and fetal brain and maternal skeletal muscle. Studies using radioactive $\left({ }^{125} \mathrm{I}^{-}\right) \mathrm{T}_{3}$ had indicated that there is little $(<10 \%)$ loss of $\mathrm{T}_{3}$ generated during incubation under the above-mentioned conditions.

\section{RESULTS}

The metabolism of $\mathrm{T}_{3}$ and $\mathrm{T}_{3} \mathrm{~S}$ by hepatic microsomes of the maternal and the fetal rat is shown in Figure 2. Maternal liver microsomes metabolized $\mathrm{T}_{3} \mathrm{~S}$ exceedingly efficiently. Some $80 \%$ or more of $\mathrm{T}_{3} \mathrm{~S}$ was consumed during its incubation with 360 $\mu \mathrm{g} / \mathrm{mL}$ microsomes for $2 \mathrm{~h}$. The majority of the consumption of $\mathrm{T}_{3} \mathrm{~S}$ by adult rat liver microsomes was explained by outer-ring
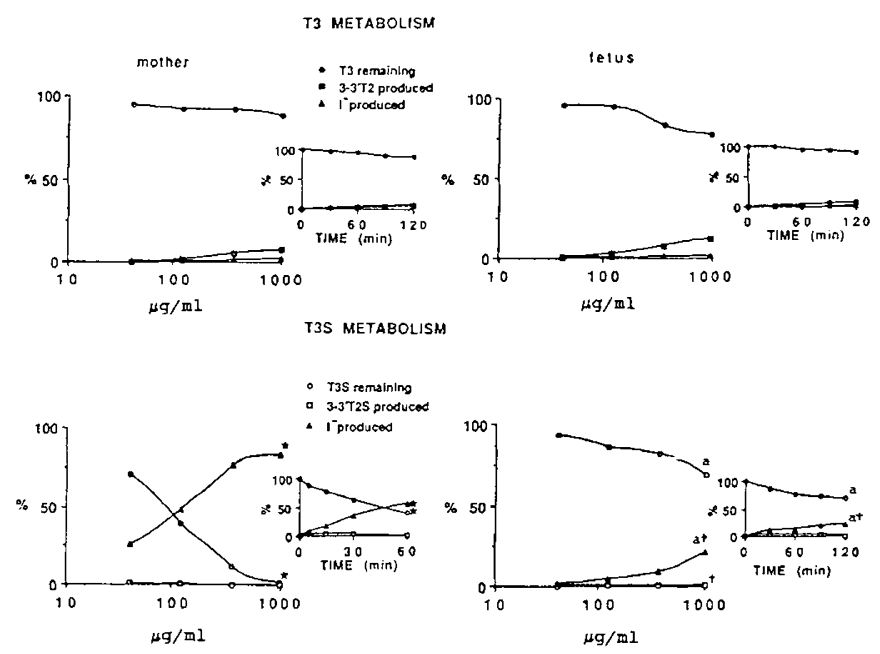

Fig. 2. Metabolism of $T_{3}$ and $T_{3} S$ by liver microsomes of maternal and fetal rat. The effect of tissue protein concentration at $2 \mathrm{~h}$ of incubation and the effect of the duration of incubation in the presence of $1 \mathrm{mg} / \mathrm{mL}$ protein (inset) were studied. Results are the means of two closely agreeing experiments using pooled fetal tissues, each from $40-50$ fetuses, and individual maternal tissues. The results were expressed as \% of ${ }^{125} \mathrm{I}_{-} \mathrm{T}_{3}$ (or ${ }^{125} \mathrm{I}-\mathrm{T}_{3} \mathrm{~S}$ ) added to the incubation mixture. Statistical evaluation of the differences in the metabolism of ${ }^{125} \mathrm{I}_{-} \mathrm{T}_{3}$ and ${ }^{125} \mathrm{I}-\mathrm{T}_{3} \mathrm{~S}$ by maternal and/or fetal tissues was performed by the analysis of covariance. Mother $v s$ fetus, $\mathrm{T}_{3} \mathrm{~S}$ metabolism, $a, p<0.05 ; \mathrm{T}_{3} v s \mathrm{~T}_{3} \mathrm{~S}$ metabolism in the mother or the fetus, $\dagger, p \leq 0.05 ;{ }^{*}, p \leq 0.01$. 
$\left(5^{\prime}-\right)$ monodeiodination with generation of iodide. Little $3,3^{\prime}-$ $\mathrm{T}_{2} \mathrm{~S}$ was demonstrable at the end of incubation. This was the case whether the studies were conducted with an incubation period of $5 \mathrm{~min}$ or $2 \mathrm{~h}$. Unlike maternal liver microsomes, however, fetal liver microsomes metabolized $\mathrm{T}_{3} \mathrm{~S}$ poorly and a large proportion $(>75 \%)$ of $\mathrm{T}_{3} \mathrm{~S}$ remained unchanged after a $2-\mathrm{h}$ incubation with fetal liver microsomes (compare mother, $p<$ 0.05 ). Reduced metabolism of $\mathrm{T}_{3} \mathrm{~S}$ by fetal liver compared with adult liver was mainly a result of its severely reduced outer-ring monodeiodination; the inner-ring metabolism of $\mathrm{T}_{3} \mathrm{~S}$ was similarly low between the fetus and adult.

$\mathrm{T}_{3}$ was metabolized similarly moderately by fetal and maternal liver microsomes (Fig. 2). Thus, $\sim 90 \%$ and $\sim 80 \%$ of ${ }^{125} \mathrm{I}-\mathrm{T}_{3}$ was still unchanged after a 2-h incubation with $1000 \mu \mathrm{g} / \mathrm{mL}$ microsomes from maternal and fetal liver, respectively. In both cases, $3,3^{\prime}-\mathrm{T}_{2}$ was the predominant product of deiodination ( 7 and $12 \%$, respectively), whereas ${ }^{125} I^{-}$liberated was less than $3 \%$.

Figure 3 shows the data on the metabolism of $\mathrm{T}_{3} \mathrm{~S}$ and $\mathrm{T}_{3}$ by cerebral cortical microsomes of the maternal and fetal rat. $\mathrm{T}_{3} \mathrm{~S}$ was poorly metabolized by both maternal and fetal tissue. Some $90 \%$ or more of substrate $\mathrm{T}_{3} \mathrm{~S}$ was still intact after a 2 -h incubation with cerebral cortical microsomes of the adult or the fetus. Interestingly, however, these tissues metabolized $\mathrm{T}_{3}$ more rapidly than $\mathrm{T}_{3} \mathrm{~S}(p<0.05)$, both in the inner ring (to $\left.3,3^{\prime}-\mathrm{T}_{2}\right)$ and the outer ring (to $\mathrm{I}^{-}$). Thus, after a $2-\mathrm{h}$ incubation with $360 \mu \mathrm{g} / \mathrm{mL}$ maternal microsomes, only $\sim 23 \%$ of ${ }^{125} \mathrm{I}_{-} \mathrm{T}_{3}$ remained unchanged, whereas $\sim 37 \%$ was monodeiodinated to ${ }^{125} \mathrm{I}-3,3^{\prime} \mathrm{T}_{2}$ and $\sim 5 \%$ to ${ }^{125} \mathrm{I}^{-}$. Under the same conditions, the corresponding values for fetal microsomes were 13,46 , and $10 \%$ respectively. In both maternal and fetal tissues, a substantial proportion of the $3,3^{\prime}-T_{2}$ generated during incubation had been deiodinated further in the inner ring to $3^{\prime}$-monoiodothyronine, and this reaction accounted for $\sim 30-35 \%$ of the starting $T_{3}$.

The deiodination of ${ }^{125} \mathrm{I}_{-} \mathrm{T}_{3}$ and ${ }^{125} \mathrm{I}-\mathrm{T}_{3} \mathrm{~S}$ by rat placental microsomes, another tissue rich in 5-monodeiodinase (20), was also studied. Some $80 \%$ or more of ${ }^{125} \mathrm{I}_{-} \mathrm{T}_{3}$ was consumed during its incubation with $60 \mu \mathrm{g} / \mathrm{mL}$ microsomes for $2 \mathrm{~h}$, mainly by innerring deiodination to ${ }^{125} \mathrm{I}-3,3^{\prime} \mathrm{T}_{2}(\sim 60 \%)$ and to a lesser degree by outer-ring deiodination to ${ }^{125} \mathrm{I}-(\sim 20 \%)$. Conversely, more than $90 \%$ of $\mathrm{T}_{3} \mathrm{~S}$ was still unchanged after a 2 -h incubation with 540 $\mu \mathrm{g} / \mathrm{mL}$ microsomes (compare $\mathrm{T}_{3}, p<0.05$ ).

The $\mathrm{T}_{3} \mathrm{~S}$ to $\mathrm{T}_{3}$ desulfation activity, as determined by incubation of $250 \mathrm{pmol}$ of $\mathrm{T}_{3} \mathrm{~S}$ with $200 \mu \mathrm{g}$ of protein of microsomes from pooled tissues of the maternal rat for $2 \mathrm{~h}$ at $37^{\circ} \mathrm{C}$, was (pmol. $\mathrm{h}^{-1} \cdot \mathrm{mg}$ protein ${ }^{-1}$ ) 55 for liver, 32 for kidney, 24 for skeletal

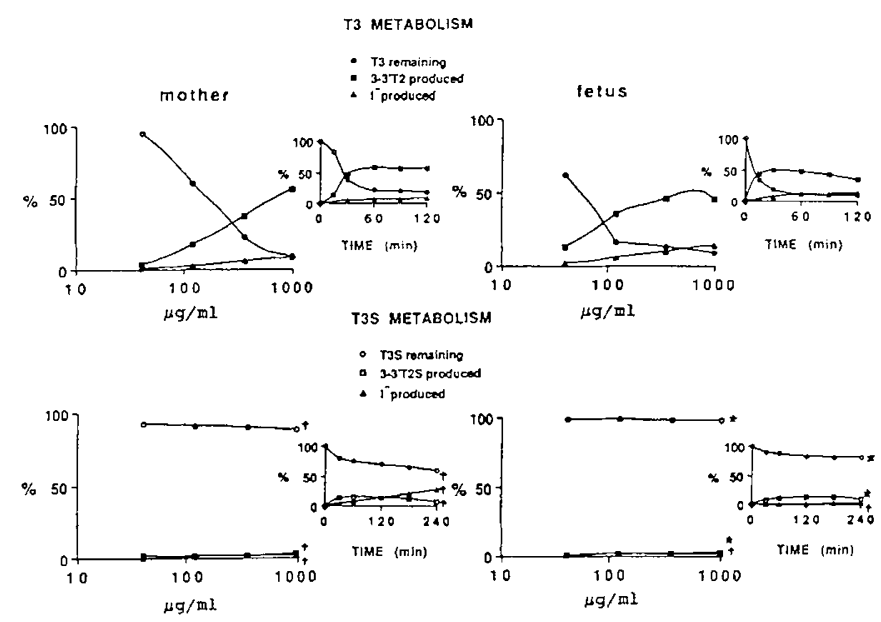

Fig. 3. Metabolism of $T_{3}$ and $T_{3} S$ by cerebral cortical microsomes of maternal and fetal rat. The effect of tissue protein concentration and duration of incubation were studied. The sources of tissues, conditions of incubation, and expression of the results were the same as described in Figure 2. $\mathrm{T}_{3}$ vs $\mathrm{T}_{3} \mathrm{~S}$ metabolism in the mother or the fetus, $\dagger, p<0.05$; $*, p \leq 0.01$. muscle, 4.9 for spleen, and 2.1 for cerebral cortex. $T_{3} S$ desulfation activity was not studied in maternal intestine because the presence of bacterial contamination might influence the results or in fetal spleen because sufficient material was not available. The $\mathrm{T}_{3} \mathrm{~S}$ to $\mathrm{T}_{3}$ desulfation activity $\left(\mathrm{pmol} \cdot \mathrm{h}^{-1} \cdot \mathrm{mg}\right.$ protein $\left.{ }^{-1}\right)$ determined using microsomes ( $200 \mu \mathrm{g}$ of protein) from pooled tissues of the fetal rat was 3.1 for cerebral cortex, 1.4 for liver, $<0.3$ for kidney, $<0.3$ for skeletal muscle, and $<0.3$ for intestine.

Figure 4 shows the Lineweaver-Burk plots (21) of the data on the conversion of $\mathrm{T}_{3} \mathrm{~S}$ to $\mathrm{T}_{3}$ by liver and cerebral cortical microsomes from the mother and a pooled $(n=40-50)$ tissue from the fetal rat. The mean $\left( \pm\right.$ SEM) of the $T_{3} S$ desulfation activity in fetal liver $[224 \pm 44 \mu \mathrm{M}$ ( $n=$ three tissue pools)] was significantly higher than that in maternal liver $[40 \pm 19 \mu \mathrm{M}(n$ $=3)](p<0.02)$. The $V_{\max }$ of the activity was lower in the fetus than in the adults, but the difference was not statistically significant $\left[1000 \pm 154\right.$ versus $2308 \pm 774 \mathrm{pmol}$ of $\mathrm{T}_{3}$ produced $\cdot \mathrm{h}^{-1}$. $\mathrm{mg}$ protein $\left.{ }^{-1}(0.05>p<0.1)\right]$. The $\mathrm{Km}$ and $\mathrm{V}_{\max }$ of $\mathrm{T}_{3} \mathrm{~S}$ desulfation activity in fetal cerebral cortex were both significantly $(p<0.05)$ higher than the corresponding values in maternal cerebral cortex $[\mathrm{Km}, 627 \pm 163(n=$ three tissue pools) versus $88 \pm 8.6(n=3) ; \mathrm{V}_{\max }, 905 \pm 135$ versus $283 \pm 7.5 \mathrm{pmol}$ of $\mathrm{T}_{3}$ produced $\cdot \mathrm{h}^{-1} \cdot \mathrm{mg}$ protein ${ }^{-1}$. The $\mathrm{Km}$ and $\mathrm{V}_{\max }$ of the $\mathrm{T}_{3} \mathrm{~S}$ to $\mathrm{T}_{3}$ desulfation activity was also studied in the maternal skeletal muscle, and the values were comparable to those in the liver $\left(\mathrm{Km}, 27 \mu \mathrm{M} ; \mathrm{V}_{\max }, 337 \mathrm{pmol}\right.$ of $\mathrm{T}_{3}$ produced $\cdot \mathrm{h}^{-1} \cdot \mathrm{mg}$ protein ${ }^{-1}$, $n=2$ ). However, little or no activity was detected in the case of the fetal skeletal muscle.
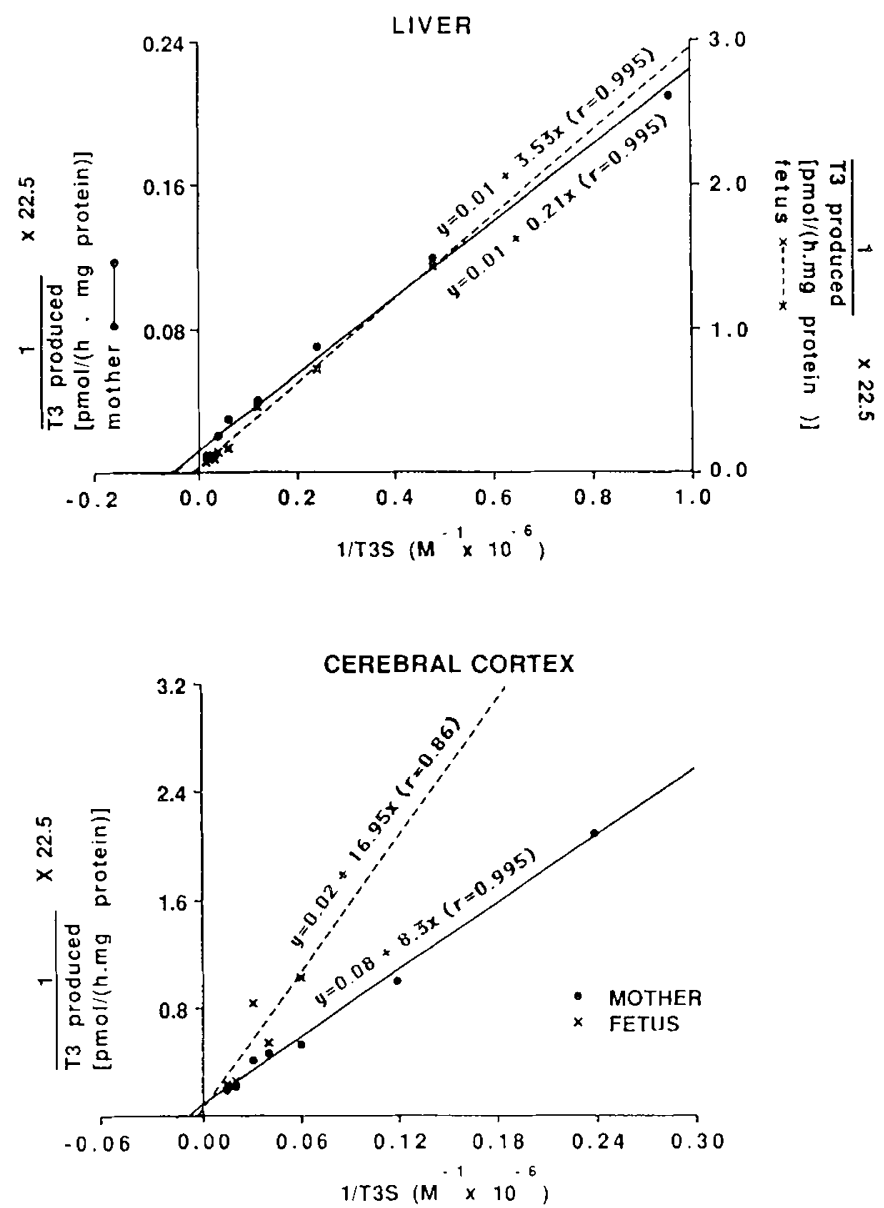

Fig. 4. Double reciprocal plots of the rate of desulfation of $T_{3} S$ to $T_{3}$ by hepatic and cerebral cortical microsomes of the maternal and fetal rat. The conditions of incubation and the method of measurement of $T_{3}$ generated during incubation of the tissue with substrate $\left(\mathrm{T}_{3} \mathrm{~S}\right)$ are described in Materials and Methods. The data in one maternal rat and a pooled sample of 40-50 fetal rats are shown. 


\section{DISCUSSION}

Thyroid hormone is critical for growth and development of the fetus. It is especially important for optimal development, differentiation, and functioning of the CNS (22). However, the extrathyroidal generation rate and serum concentration of the most active thyroid hormone, $\mathrm{T}_{3}$, are reduced in the fetus as they are in adults with nonthyroidal systemic illnesses (euthyroid sickness syndrome) or complete fasting (23-25). It has been suggested that the reduced serum $T_{3}$ and $T_{3}$ production rate in the above-mentioned conditions are part of a homeostatic arrangement serving to reduce catabolism and promote optimal anabolism.

Accordingly, fetal tissues are very active in degrading $T_{3}$ by inner-ring deiodination, whereas the rate of $\mathrm{T}_{3}$ production by outer-ring deiodination of $\mathrm{T}_{4}$ is strongly reduced compared with the adults. It is possible that increased $T_{3} 5$-monodeiodination in the placenta contributes to its function as a barrier to the transport of active thyroid hormones from the mother to the fetus (20).

Our data show that, unlike $T_{3}, T_{3} S$ is poorly deiodinated by fetal tissues, both in the outer and in the inner ring. These findings are compatible with the high levels of $T_{3} S$ measured in fetal serum. We also demonstrated that microsomes from both adult and fetal tissues are able to desulfate $T_{3} S$ to generate $T_{3}$. $\mathrm{T}_{3} \mathrm{~S}$ is considered to have no biologic activity per se, and in normal adults it is quickly deiodinated. Therefore, sulfation of $\mathrm{T}_{3}$ appears to be a pathway facilitating deiodination in normal adults in whom the necessary amount of thyroid hormone $\left(\mathrm{T}_{3}\right)$ to the tissues derives from $5^{\prime}$-monodeiodination of $T_{4}\left(\right.$ to $\left.T_{3}\right)$. The role of the sulfation pathway might, however, be different in certain situations in which serum $T_{3}$ and $T_{3}$ production rates are reduced, e.g. in fetal life and systemic nonthyroidal illnesses. Our data suggest that, by creating differences in the metabolism of $T_{3} S$ and $T_{3}$ and by creating higher serum levels of $T_{3} S$ in the fetus than in the adult, nature has devised a means by which most fetal tissues are exposed to subnormal levels of the highly active and catabolic thyroid hormone, $\mathrm{T}_{3}$, whereas tissues in which $T_{3}$ is critical for growth, development, and/or differentiation, e.g. CNS, receive the hormone when needed as a result of their ability to generate it locally by desulfation of $\mathrm{T}_{3} \mathrm{~S}$. More rapid metabolism of $T_{3}$ than $T_{3} S$ by fetal tissues may facilitate this selectivity in the supply of $\mathrm{T}_{3}$ to the tissues. $\mathrm{T}_{3} \mathrm{~S}$ is considered to have little or no TSH-suppressive activity (12); therefore, its high serum levels would have little or no adverse influence on the growth and development of the fetal thyroid. Clearly, further work is necessary to support or refute this hypothesis. However, it appears likely, as in the case of monodeiodination of $T_{4}$ to more active $T_{3}$ or less active $\mathrm{rT}_{3}$, that a relative balance in the ability of tissues to sulfate thyroid hormone(s) or desulfate their sulfoconjugates to active hormone is an important control mechanism that regulates, in a selective manner, the supply of thyroid hormones to different tissues and perhaps even different parts of a tissue.

\section{REFERENCES}

1. Chopra JJ, Solomon DH, Chopra U, Wu SJ, Nakamura Y, Fisher DA 1978 Pathways of metabolism of thyroid hormones. Recent Prog Horm Res $34: 521-567$

2. Wartofsky L, Burman KD 1982 Alterations in thyroid function in patients with systemic illness: the "euthyroid sick syndrome." Endocr Rev 3:164-217

3. Engler D, Burger AG 1984 The deiodination of iodothyronines and of their derivatives in man. Endocr Rev 5:151-184

4. Chopra IJ, Boado RJ, Geffner DL, Solomon DH 1988 A radioimmunoassay for measurement of thyronine and its acetic acid analog in urine. $J$ Clin Endocrinol Metab 67:480-487

5. Willets P, Crossley DN, Ramsden DB, Hoffenberg R 1979 The role of thyronine in thyroid hormone metabolism. J Clin Endocrinol Metab 49:658-660

6. Powell GM, Olavesen AH 1981 The fate of sulfate esters in vivo. In: Mulder GJ (ed) Sulfation of Drugs and Related Components. CRC Press, Boca Raton, FL, pp 187-212

7. Otten MH, Mol JA, Visser TJ 1985 Sulfation preceding deiodination of iodothyronines in rat hepatocytes. Science 221:81-83

8. Mol JA, Visser TJ 1985 Rapid and selective inner ring deiodination of thyroxine sulfate by rat liver deiodinase. Endocrinology 117:8-12

9. Elkman Rooda SJ, Rutgers M, Kaptein F, Visser TJ 1988 Increased plasma $3,5,3^{\prime}$-triiodothyronine sulfate in rats with inhibited type I iodothyronine deiodinase activity, as measured by radioimmunoassay. Endocrinology 124:740-745

10. Eelkman Rooda SJ, Kaptein E, Visser TJ 1989 Serum triiodothyronine sulfate in man measured by radioimmunoasay. J Clin Endocrinol Metab 69:552556

11. Eelkman Rooda SJ, Otten MH, VanLoon MAC, Kaptein E, Visser TJ 1989 Metabolism of triiodothyronine in rat hepatocytes. Endocrinology 125:21872197

12. LoPresti JS, Mizuno L, Nimalysuria A, Anderson KP, Spencer CA, Nicoloff JT 1991 Characteristics of 3,5,3'-triiodothyronine sulfate metabolism in euthyroid man. J Clin Endocrinol Metab 73:703-709

13. Chopra IJ, Wu SY, Chua Teco GN, Santini F 1992 A radioimmunoassay for measurement of 3,5,3'-triiodothyronine sulfate $\left(\mathrm{T}_{3} \mathrm{~S}\right)$ : studies in thyroidal and nonthyroidal diseases, pregnancy and neonatal life. $J$ Clin Endocrinol Metab 74 (in press)

14. Kung MP, Spaulding SW, Roth JA 1988 Desulfation of 3,5,3'-triiodothyronine sulfate by microsomes from human and rat tissues. Endocrinology 122:11951200

15. Mol JA, Visser TJ 1985 Synthesis and some properties of sulfate esters and sulfamates of iodothyronines. Endocrinology 117:1-7

16. Maciel RMB, Ozawa J, Chopra IJ 1979 Subcellular localization of thyroxine and reverse triiodothyronine outer ring monodeiodinating activities. Endocrinology 104:365-371

17. Boado JR, Chopra IJ 1989 A study of hepatic low $\mathrm{Km}$ iodothyronine 5'monodeiodinase. Endocrinology 124:2245-2251

18. Wu SJ, Chopra IJ, Nakamura Y, Solomon DH, Bennet LR 1976 A radioimmunoassay for measurement of $3,3^{\prime}$-L-diiodothyronine $\left(T_{2}\right)$. J Clin Endocrinol Metab 43:682-685

19. Chopra IJ, Ho RS, Lam R 1972 An improved radioimmunoassay of triiodothyronine in serum: its application to clinical and physiological studies. J Lab Clin Med 80:729-739

20. Roti E, Farg SL, Braverman LE, Emerson CH 1982 Rat placenta is an active site of inner ring deiodination of thyroxine and $3,3^{\prime}, 5$-triiodothyronine. Endocrinology 110:34-37

21. Lineweaver H, Burk D 1934 The determination of enzyme dissociation constants. J Am Chem Soc 56:658-666

22. Calvo R, Obregon MJ, De Ona CR, Escobar de Rey F, Morreale de Escobar G 1990 Congenital hypothyroidism, as studied in rats. J Clin Invest 86:889899

23. Chopra IJ, Sack J, Fisher DA 1975 3,3' $5^{\prime}$-triiodothyronine (reverse $T_{3}$ ) and 3,3'5-triiodothyronine $\left(\mathrm{T}_{3}\right)$ in fetal and adult sheep: studies of metabolic clearance rates, production rates, serum binding and thyroidal content relative to thyroxine. Endocrinology $97: 1080-1088$

24. Fisher DA, Dussault JH, Sack J, Chopra IJ 1977 Ontogenesis of hypothalamopituitary function and metabolism in man, sheep and rat. Recent Progr Horm Res 33:59-116

25. Chopra IJ, Hershman JM, Nicoloff JT, Pardridge WP 1983 Thyroid function in nonthyroidal illnesses. Ann Intern Med 98:946-957 